\title{
KEKERASAN YANG DILAKUKAN OLEH FRONT PEMBELA ISLAM DI DENGOK KANDANGSEMANGKON PACIRAN LAMONGAN PERSPEKTIF HUKUM PIDANA ISLAM
}

\author{
\begin{tabular}{r|r} 
Azilatul Rohmaniyah & Sedangharjo Brondong Lamongan \\
mayrooza@gmail.com &
\end{tabular}
}

Abstract: This article discusses the violence conducted by the Islamic Defender Front in Dengok Kandangsemangkon village -Paciran- Lamongan. Violence committed by the members of FPI in Dengok Kandangsemangkon village is in the form of persecutions. It has fulfilled the elements that exist in Islamic criminal law which classified the criminal act on other than the soul. The violations which done are cutting ears, beating on back, wounding head and cheeks. In the Islamic criminal law of mass violence causing injury other people is not directly regulated, but it can be qualified as persecution of jarimah conducted by more than one person. In this case, the perpetrator can be punished by qishâsh. However if he is forgiven by the family, it can be replaced by diyat. Indirect actor in this case is sentenced by ta'zir based on judge's decition.

Keywords: Violence, Islamic Defenders Front, Islamic Criminal Law.

Abstrak: Artikel ini membahas tentang kekerasan yang dilakukan Front Pembela Islam di dusun Dengok Desa Kandangsemangkon Kecamatan Paciran Kabupaten Lamongan. Kekerasan yang dilakukan oleh anggota FPI yang ada di Dusun Dengok Desa Kandangsemangkon adalah berupa penganiayaan-penganiayaan. Hal ini telah memenuhi unsur-unsur yang ada pada hukum pidana Islam yang digolongkan pada tindak pidana atas selain jiwa. Adapun yang dilakukan antara lain adalah pemotongan telinga, pemukulan mengenai punggung, pelukaan pada kepala dan pipi. Dalam hukum pidana Islam kekerasan massa yang mengakibatkan luka orang lain tidak diatur secara langsung, namun dapat dikualifikasikan sebagai jarîmah penganiayaan yang dilakukan secara bersama-sama, maka qishâsh dijatuhkan atas pelaku aktif, yaitu pelaku langsung, jika dimaafkan bisa diganti diyat. Pelaku tidak langsung dalam hal ini dijatuhi hukuman ta'zir yang diserahkan kepada hakim.

Kata Kunci: Kekerasan, Front Pembela Islam, hukum pidana Islam. 


\section{Pendahuluan}

Sejak pertama kali muncul dalam wacana publik, pada tanggal 17 Agustus 1998, Front Pembela Islam (FPI) sudah menampakkan watak gerakannya yang militan, namun rapi. FPI tidak segan-segan bentrok fisik dengan pihak musuh (orang yang melakukan kemaksiatan), selama aksi yang dilakukan FPI itu berada dalam koridor hukum dan tuntutan syariat Islam. ${ }^{1}$

Selama ini, sebagian kelompok memandang agama sebagai sumber konflik sosial. Hal ini diakibatkan konflik di mana ajaran maupun nilai agama memotivasi dan mempengaruhi seseorang dalam bertindak secara tegas terhadap perilaku yang menyimpang dari ketentuan agama, padahal perilaku yang menyimpang dari norma keagamaan itu jarang terkena sanksi hukum atau tindakan tegas dari negara melalui aparat kepolisian. Realitas tersebut memungkinkan agama dapat berhadapan secara langsung dengan pihak-pihak negara seperti polisi atau pengadilan. Negara di dalamnya terdapat hukum maupun perundangan untuk ditaati, dan negara akan bertindak tegas terhadap pihak-pihak yang dianggapnya telah melampaui atau melanggar hukum positif negara (Undang-Undang). ${ }^{2}$

Konflik yang melibatkan agama dapat disebabkan oleh beberapa hal, tetapi secara keseluruhan disebabkan oleh sentimensi atau aspek emosional keagamaan. Permasalahan emosional ini merupakan hal yang paling pribadi, sehingga ketika ada suatu kasus yang membangkitkan sisi emosional para pemeluk agama, maka konflik akan muncul, seperti halnya yang sering dilakukan oleh organisasi masyarakat Front Pembela Islam (FPI). ${ }^{3}$

Sejak didirikan pada tahun 1998, FPI telah memainkan perannya sebagai pembela harkat dan martabat Islam dan umat Islam yang boleh dikatakan sebagai salah satu yang terdepan. Pembelaannya terhadap Islam dan umat Islam tidak hanya terhenti pada konteks lokal maupun nasional. ${ }^{4}$

\footnotetext{
1 Syahrul Efendi dan Yudi Pramuko, Rahasia Sukses Dakwah Habih-FPI Gempur Playboy (Jakarta: Devisi Buku Dakwah dan Bisnis, 2006), 52.

2 Setiawan, Orientasi Tindakan dalam Gerakan Nahi Munkar Laskar Front Pembela Islam (Jogjakarta), -Skripsi- (Jogjakarta: Fakultas Ushuluddin Universitas Islam Negeri Sunan Kalijaga, 2009) 1.

${ }^{3}$ lbid.

${ }^{4}$ Syahrul Efendi dan Yudi Pramuko, Rahasia Sukses Dakwah ........ 63.
} 
Untuk kasus lokal seperti Jakarta, kesuksesannya dalam "memaksa" gubernur DKI Jakarta untuk mengeluarkan surat edaran tentang pelarangan membuka tempat hiburan maksiat selama bulan Ramadhan, menjadi sejarah emas FPI yang berjuang dalam pemberantasan maksiat. Selama tiga Ramadhan berturut-turut (19982000), meskipun pada tahun 1999 FPI terpaksa melakukan pendudukan terhadap balai kota karena tuntutannya tidak diindahkan oleh pemerintah daerah, tuntutan FPI terus diakomodir oleh pemerintah DKI Jakarta. ${ }^{5}$

Dalam mencapai tujuan amar ma'ruf, FPI mengutamakan metode bijaksana dan lemah lembut melalui langkah-langkah seperti, mengajak dengan hikmah (kebijaksanaan, lemah lembut), memberi mauidzah hasanah (nasihat yang baik), dan berdiskusi dengan cara yang terbaik. Sedangkan dalam melakukan nahi munkar, FPI mengutamakan sikap yang tegas melalui langkah-langkah seperti, menggunakan kekuatan/kekerasan bila mampu dan menggunakan lisan serta tulisan. Bila kedua langkah tersebut tidak mampu dilakukan maka nahi munkar dilakukan dengan menggunakan hati yang tertuang dalam ketegasan sikap, ${ }^{6}$ artinya mendidihnya hati karena marah terhadap kemungkaran, membenci kedzaliman dan menolak kerusakan.

Ketika hati dipenuhi amarah, kebencian, penolakan dan pemberontakan ini, akan ada persiapan mental untuk pemberontakan yang nyata dan intensif, demi memberantas kedzaliman agar tidak semakin sewenang-wenang, membesar, dan merajalela. Hal tersebut karena perubahan itu tidak dimulai dari kekosongan, melainkan didorong oleh motif-motif psikologis yang menumbuhkan semangat dan pembelaan diri, sehingga semua tertuang dalam ketegasan sikap untuk tidak menyetujui segala bentuk kemunkaran. ${ }^{7}$ Tujuan lain dibentuknya FPI adalah untuk membantu pemerintah dalam menumpas problem

\footnotetext{
${ }^{5}$ Tahun 1999 dengan surat Edaran Gubernur No. 62/SE/1999 dan tahun 2000 dengan surat Edaran Gubernur No. 64/SE/2000. Lihat A-Habib Muhammad Rizieq bin Husein Syihab, Dialog Amar Ma'ruf Nahiy Munkar, Menjawab Berbagai Tuduhan terhadap Gerakan Amar Ma'ruf Nahiy Munkar di Indonesia (Jakarta: PIS, tt.) dan Sabili, No 13 Tb. VII 13 Desember 2000, 82.

6 A-Zastrouw, Gerakan Islam Simbolik Politik Kepentingan FPI (Yogjakarta: PT LKiS Pelangi AksaraYogjakarta, 2006), 91.

${ }^{7}$ Yusuf Qardhawi, Fiqih Jihad sebuah Karya Monumental Terlengkap tentang Jihad menurut alQur'an dan Sunnah (Bandung: PT Mizan Pustaka, 2010), 113.
} 
sosial kemasyarakatan, seperti prostitusi, perjudian, serta transaksi minuman keras dan narkoba. ${ }^{8}$

Penumpasan kemunkaran yang dilakukan FPI berdasarkan Surat Ali Imran ayat 104 yang berbunyi:

Dan hendaklah ada di antara kamu segolongan umat yang menyeru kepada kebajikan, menyuruh kepada yang ma'ruf dan mencegah dari yang munkar merekalah orang-orang yang beruntung. ${ }^{9}$

Menurut Front Pembela Islam, apabila penumpasan kemunkaran itu dilakukan hanya dengan lisan, tulisan dan hati maka tidak akan dapat merubah kedzaliman secara keseluruhan, yang ada hanya bertambahnya kemunkaran yang merajalela dalam suatu daerah. Disamping masyarakatnya, polisi yang merupakan instansi negara yang seharusnya menjaga nilai-nilai keislaman yang sudah tertanam dalam masyarakat telah melakukan kemunkaran bersama masyarakatnya. Inilah yang menjadikan amarah anggota FPI semakin bertambah, sehingga timbul adanya pertikaian antara golongan peminum minuman keras dengan anggota FPI, seperti halnya kasus di Dusun Dengok Desa Kandang Semangkon Kecamatan Paciran Kabupaten Lamongan. Kasus ini berawal dari adanya anggota Front Pembela Islam melakukan kekerasan terhadap 3 orang peminum minuman keras. Setelah adanya kejadian tersebut, sejumlah warga sebanyak 20 orang melakukan aksi pembalasan. Aksi tersebut memancing emosi anggota FPI dan akhirnya 42 anggota FPI menyerang warga dengan tujuan membalas perbuatan atas penganiayaan istri dari salah satu anggota FPI. Akibat aksi tersebut, rusaklah kaca jendela rumah, TV, dan enam sepeda motor. Sebelum terjadinya kasus di atas, anggota FPI memang sering bertindak anarkis dalam mengemban visi dan misinya di daerah tersebut, salah satu contoh dari masalah kecil yaitu ketika terdapat sepasang pemuda duduk bersama di sebuah tempat publik. Anggota FPI yang mengetahui kejadian tersebut langsung memukul pasangan itu tanpa adanya tutur kata lewat lisan terlebih dahulu. Dari sinilah timbul anggapan negatif dari masyarakat di desa setempat. ${ }^{10}$

\footnotetext{
${ }^{8}$ A-Zastrouw, Gerakan Islam ..., 93.

${ }^{9}$ Departemen Agama, Al-Qur'an dan Terjemahnya (Jakarta: Surya Cipta Aksara Surabaya, 1993), 93.

${ }^{10} \mathrm{http}: / /$ www.tempo.co/read/news/2013/08/12/06350384i//ni-Kronologi-Bentrok-FPI-danWargadi-Lamongan.
} 
Menurut al-Qur'an, dakwah dalam rangka amar ma'ruf nahi munkar harus dilakukan dengan tiga metode yaitu dengan mengemukakan hikmah (perkataan yang tegas dan benar yang dapat membedakan antara yang haq dan yang batil), pengajaran yang baik, dan diskusi atau berdebat dengan cara yang baik untuk menaruh perhatian, karena cara yang salah akan berakibat enggan menerima kebenaran. sesuai QS al-Nahl ayat 125:

Serulah (manusia) kepada jalan Tuhanmu dengan hikmah dan pelajaran yang baik dan bantahlah mereka dengan cara yang baik. Sesungguhnya Tuhanmu Dialah yang lebih mengetahui tentang siapa yang tersesat dari jalanNya dan Dialah yang lebih mengetahui orang-orang yang mendapat petunjuk. ${ }^{11}$

Dengan adanya ketidak sesuaian antara teori dalam al-Qur'an dan pelaksanaan mengenai metode amar ma'ruf nahi munkar Front Pembela Islam inilah, maka penulis semakin tertarik untuk mengangkat tulisan ini dengan judul kekerasan yang dilakukan Front Pembela Islam di Dengok Kandangsemangkon Paciran Lamongan perspektif hukum Islam.

\section{Gambaran Umum Wilayah Dengok Kandangsemangkon Paciran Lamongan}

Desa Kandangsemangkon memiliki luas wilayah kurang lebih 457,9 hektar dan bisa dibagi menjadi tiga karakteristik wilayah daratnya yaitu: tegal/ladang $287 \mathrm{Ha}$, pemukiman $140 \mathrm{Ha}$ dan lainnya $59 \mathrm{Ha}$, yang terdiri atas lapangan umum, pasar, kuburan, tambak dan fasilitas lainnya. Batas wilayah administrasi desa Kandangsemangkon kecamatan Paciran yaitu: sebelah utara berbatasan dengan laut Jawa, sebelah selatan berbatasan dengan desa Dadapan kecamatan Solokuro, sebelah barat berbatasan dengan kelurahan Blimbing kecamatan Paciran, sedangkan sebelah timur berbatasan dengan desa Paciran kecamatan Paciran. Desa Kandangsemangkon terdiri dari 2 dusun Kandang dan dusun Dengok dengan 2 kepala dusun, 13 Rukun Warga dan 31 Rukun Tetangga. Sedang kondisi topografi desa Kandangsemangkon kecamatan Paciran adalah datar dan termasuk agak rendah dibanding dengan dusun lain, dengan kondisi wilayah desa di sebelah utara berbatasan dengan laut Jawa. ${ }^{12}$

\footnotetext{
${ }^{11}$ Hamka, Tafsir Al-Azhar, Juz XVII (Surabaya: Bina Ilmu, 1981), 319.

${ }^{12}$ Salim, Wawancara, Lamongan, 05 juni 2014.
} 
Berdasarkan data administrasi pemerintahan desa awal Januari 2014, jumlah penduduk desa Kandangsemangkon adalah terdiri dari 1627 kepala keluarga, dengan jumlah total 7875 jiwa, dengan rincian 3985 laki-laki dan 3890 perempuan. Jarak tempuh desa Kandangsemangkon ke kecamatan adalah 5 KM, yang dapat ditempuh dengan waktu sekitar 10 menit. Sedangkan jarak tempuh ke kabupaten adalah $45 \mathrm{KM}$, yang dapat ditempuh dengan waktu sekitar 60 menit.

\section{Sejarah Berdirinya FPI di Dusun Dengok Desa Kandangsemangkon}

FPI (Front Pembela Islam) pertama kali berdiri di dusun Dengok telah diprakarsai oleh FUI (Forum Ukhuwah Islamiyah) yang keanggotaannya terdiri dari semua ta'mir masjid dan mushalla sePantura. Kemudian ada keluhan dari masyarakat supaya FUI mengambil bagian di dalam masalah kerusakan umat yang berkaitan dengan kemunkaran dan kema'siatan, khususnya dalam masalah narkoba. Pada waktu itu, narkoba sangat merajalela, sehingga menimbulkan adanya preman-preman yang dapat meresahkan masyarakat di sekitarnya. Mereka tidak hanya mengkonsumsi narkoba, tetapi juga masyarakat di sekeliling telah menjadi korbannya, contohnya adalah Ahli Ma'asi telah makan bakso dengan teman-temannya, setelah diminta untuk membayar malah mereka menggulingkan gerobaknya, selain itu ada yang naik becak, namun ketika membayar malah menodongkan pedangnya. Kemudian FUI menfasilitasi terbentuknya Front barisan perlawanan terhadap kema'siatan narkoba, khususnya ketika itu. Selain di dusun Dengok di Paciran juga ada laskar yang dibentuk dengan tujuan yang sama yaitu Laskar UIP (Laskar Umat Islam Pantura).

Pada waktu itu, organisasi yang konsen dalam penanganan terhadap persoalan narkoba hanyalah kedua organisasi itu, oleh karena itu forum ini berijtihad untuk menggabungkan diri dengan FPI. Hal ini dianggapnya organisasi FPI sudah mapan, akan tetapi sebelum bergabung forum-forum ini sudah menjalankan aksi-aksi yang tegas, kemudian dideklarasikan di Jompong dan mengundang Habib Rizieq untuk bersosialisasi. Setelah itu, kedua organisasi tersebut resmi menjadi anggota FPI Lamongan. Dalam perkembangan salanjutnya, ketua dari forum ini yaitu Zainal Anshori S.Ag, tidak sepaham dengan pemahaman Habib Rizieq sehingga keluar dari organisasi FPI. Meskipun mereka 
keluar dari organisasi FPI mereka tetap menjalankan aksi-aksi sebagaimana yang telah diajarkan di organisasi FPI. ${ }^{13}$

\section{Struktur dan Format Organisasi}

Struktur organisasi yang ada di Lamongan ini termasuk DPC (Dewan Pengurus Cabang) yang diketuai oleh Zainal Anshori S.Ag dengan wakil ketua KH. Abdul Hakam Mubarok, Lc, Drs. Alabib Rifa’i, ustadz Asfandi Baja. Sekertaris H. Arief Wahyudi dengan wakil Handrix Irawan, SE, dan dibendaharai oleh Fuad Walid S.Ag dengan wakil bendahara Muji Ilyas. ${ }^{14}$

Di daerah ini, FPI tidaklah memiliki konstitusi yang jelas dan baku, meskipun terdapat struktur organisasi mereka tidak memiliki aturan main yang jelas. Mekanisme pengambilan kebijakan dan hubungan antar organ dalam organisasi hanya didasarkan pada kesepakatan semata. Gerakan ini lebih mengutamakan solidaritas emosional daripada mekanisme formal organisasi. Dengan kata lain, FPI sebenarnya bukan organisasi massa, melainkan komunitas yang melakukan gerakan untuk mencapai tujuan bersama. Orientasi gerakan ini juga bukanlah pada bentuk kelembagaan, melainkan pada gerakan untuk menumpas kemaksiatan. Oleh karena organisasi FPI berorientasi pada gerakan maka ia tidak mempedulikan format dan bentuk kelembagaan. Mekanisme organisasi juga tidak ditentukan secara rinci dan baku, tetapi ditetapkan secara temporal dan kondisional sesuai dengan kebutuhan gerakan. ${ }^{15}$

FPI di Dusun Dengok beranggotakan kurang lebih 200 orang. Untuk pengrekrutan anggota, FPI tidak melakukan rekrutmen secara permanen dan sistematis. Pengikut utama yang menyatukan anggota FPI adalah setiap orang yang bersedia menerima garis perjuangan FPI, memiliki loyalitas kepada pemimpin dan siap melaksanakan amanat dari pemimpin yang dibebankan kepadanya. ${ }^{16}$

Secara sosiologis, keanggotaan FPI kebanyakan dari kelompok preman. Kelompok ini direkrut oleh FPI melalui pendekatan personal yang dilakukan oleh para pemimpin FPI. Para preman ini pada umumnya diarahkan untuk menjadi anggota laskar FPI. Mereka tidak

\footnotetext{
${ }^{13}$ Anshor, Wawancara, Lamongan, 09 juni 2014.

${ }^{14} \mathrm{Ibid}$.

${ }^{15} \mathrm{lbid}$.

${ }^{16}$ Al-Zastrow, Gerakan Islam Simbolik..., 101.
} 
dibekali pendidikan agama yang mendalam terlebih dahulu, tetapi lebih banyak dididik latihan fisik untuk melakukan sweeping, penggerebekan dan demonstrasi. ${ }^{17}$

\section{Pemahaman FPI tentang Amar Ma'ruf Nahi Munkar}

Amar ma'ruf nahi munkar merupakan dua kalimat yang masingmasing memiliki muatan. Amar ma'ruf adalah mengajak kepada yang baik dan nahi munkar adalah mencegah orang berbuat munkar, dua hal ini merupakan kewajiban bagi orang Islam. sementara kewajiban ini memiliki gaya yang berbeda, amar ma' ruf, harus dilakukan dengan lemah lembut, santun, hikmah dan bila perlu berdebat maka berdebat dengan baik. Akan tetapi kalau nahi munkar (mencegah kemunkaran) sesuai yang ditentukan Rasulullah dalam sabdanya:

Barang siapa melihat kemunkaran, maka ubahlah dengan tangannya (bila mampu), bila tidak mampu maka ubahlah (berantaslah) dengan lidahnya, (yaitu memberinya peringatan yang baik, boleh keras dan boleh juga lemah, asal melihat mana yang bermanfaat untuk agama). Apabila masih tidak mampu maka cukup (benci) di hati. Dan itulah iman yang paling lemah. ${ }^{18}$

Berdasarkan hadis di atas, FPI memahami bahwa barangsiapa mereka melihat kemunkaran maka diubah dengan tangannya atau tegas. Jadi dalam mengambil jalan dakwah atau yang dikedepankan dalam nahi munkar adalah merubah dengan tangan, di sinilah kenapa FPI sering berbenturan dengan ahli maksiat. Proses dakwah sudah simultan, tidak bisa dipisahkan antara proses dakwah yang dilakukan FPI di lapangan dengan dakwah yang dilakukan ulama di mimbar-mimbar. Masyarakat dipandang salah dalam mempresepsikan bahwa FPI di lapangan merupakan sesuatu yang berdiri sendiri, sehingga perlu proses yang panjang dalam berdakwah. Kerangka dakwah antara da'i-da'i di mimbar dan di lapangan itu sudah satu rangkaian, sehingga FPI tidak perlu untuk berdakwah terlebih dahulu dalam lapangan. Karena warga juga sudah tahu mana yang benar dan mana yang salah. Banyak da'i-da'i dan ulama tidak seimbang karena hanya memilih dakwah atau amar ma'ruf saja. Bapak Anshor menyatakan bahwa:

\footnotetext{
${ }^{17}$ Anshor, Wawancara, Lamongan, 03 Juni 2014.

${ }^{18}$ Al-Imam Abu Zakariya Yahya bin Syarif An-Nawawi ad-Damsyiqi diterjemahkan oleh Mahrus Ali, Riyâdh ash-Shâlihîn (Surabaya: al-Hidayah, 1997), 268.
} 
"orang menanam padi meskipun sudah dipilih bibit yang baik dan peliharaannya dengan baik akan tetapi hamanya tidak diberantas, maka tidak akan mendapatkan hasil, begitu juga mendidik anak dengan pendidikan yang baik akan tetapi lingkungannya para ahli maksiat yang tidak pernah diberantas, maka anak kita akan ikut juga karena pengaruh lingkungan". ${ }^{19}$

Petani yang baik dan cerdas adalah yang menanam padi, memupuk dan memeliharanya sambil memberantas hama mulai dari saat penanaman hingga saat panen tiba. Insyaallah petani akan mendapatkan panen yang memuaskan. Kalaupun si petani hanya menanam padi dan tidak memiliki kemampuan untuk memberantas hama maka petani meminta bantuan pihak lain untuk memberantas hamanya. ${ }^{20}$ Amar ma'ruf dan nahi munkar jika tidak seirama, maka tidak akan menuai hasilnya. Jadi tidak dibenarkan di dalam Islam membiarkan kemaksiatan karena adzabnya akan lebih besar.

"Sifat amar ma' ruf adalah tidak memaksa, jadi kalau kamu mau ya silahkan tapi kalau tidak mau ya tidak papa akan tetapi sifat nahi munkar itu memaksa, kalau orang yang tidak pernah kelapanagn biasanya suka nutoh (menyalahkan). Jangankan dengan kekerasan orang mabuk itu dengan halus saja jika dia punya teman banyak, maka mereka pasti akan lebih berani". ${ }^{21}$

Resiko nahi munkar lebih besar dari pada melakukan dakwah atau amar ma'ruf. Gaya atau metode kekerasan yang dilakukan oleh FPI adalah dilahirkan dan dididik dari ahli maksiat itu sendiri. Karena dahulu sebelum organisasi FPI ini berdiri di dusun Dengok banyak preman-preman yang terkenal garang-garang seperti halnya suka bacok, suka mabuk dan lain sebagainya sampai preman-preman Surabaya tidak berani masuk ke kawasan Pantura. Akan tetapi masyarakat memaklumi atau dianggap wajar adanya pemuda-pemuda seperti itu. Oleh karena itu apabila preman-preman diadili oleh FPI, maka seakan-akan organisasi FPI yang disalahkan. ${ }^{22}$

\footnotetext{
${ }^{19}$ Anshor, Wawancara, Lamongan, 03 Juni 2014.

${ }^{20}$ Al-Habib Muhammad Rizieq Husein Syihab, Dialog FPI: Amar Ma'ruf Nahi Munkar (Jakarta: CV Ibnu Sidah, 2013), 58.

${ }^{21}$ Anshor, Wawancara, Lamongan, 03 Juni 2014.

${ }^{22} \mathrm{lbid}$.
} 


\section{Kekerasan yang Dilakukan oleh Front Pembela Islam di Dengok Kandangsemangkon Paciran Lamongan}

Kasus kekerasan yang terjadi di Dusun Dengok Desa Kandang Semangkon Kecamatan Paciran Kabupaten Lamongan, berawal dari adanya anggota Front Pembela Islam melakukan kekerasan terhadap 3 orang peminum minuman keras. Setelah adanya kejadian tersebut, sejumlah warga sebanyak 20 orang melakukan aksi pembalasan. Aksi tersebut memancing emosi anggota FPI dan akhirnya 42 anggota FPI menyerang warga dengan tujuan membalas perbuatan atas penganiayaan istri dari salah satu anggota FPI. Akibat aksi tersebut, rusaklah kaca jendela rumah, TV, dan enam sepeda motor.

Berikut penjelasan kronologi kasus dari berbagai pihak:

1. Kronologi kasus versi bapak Anshor selaku ketua Front Pembela Islam

Bentrokkan itu bermula ketika puluhan pemuda yang berasal dari Blimbing, Brondong dan Sedayu berkumpul di suatu tempat yang berada di Gowah. Kemudian datang sejumlah anggota FPI yang melakukan sweeping kepada puluhan pemuda yang diduga sedang melakukan pesta miras. Sempat terjadi cekcok dalam sweeping tersebut. Rupanya, aksi sweeping yang dilakukan oleh Anggota FPI ini memicu kekecewaan puluhan pemuda itu, hingga akhirnya puluhan anggota pemuda menghampiri rumah Faruk di Gowah dan melakukan penganiayaan terhadap istri Faruk dan merusak kendaraan serta dua rumah. Setelah adanya penyerangan tersebut, FPI, yang dipimpin Faruk, menyatukan anggota dan akhirnya FPI mendatangi rumah Muklis selaku ketua geng di rumahnya di Dusun Dengok untuk melakukan penyerangan balik terhadap anggota ahli narkoba dan minum-minuman keras. ${ }^{23}$

2. Kronologi kasus versi Bapak Sutiono selaku Kaur Pullahinfodok Pid Bidhumas di Kapolda Surabaya Jawa Timur

Menurut kepolisian Daerah Jawa Timur berdasarkan laporan polisi bernomor: LP/23/VIII/2013/2013/Jatim/Res Lamongan/Sek Paciran mengungkap kronologis bentrok anggota Front Pembela Islam Lamongan di Dusun Dengok, Desa Kandangsemangkon Kecamatan Paciran Kabupaten Lamongan, kejadian bermula pada hari kamis tanggal 8 agustus 2013 sekitar pukul 00:10 WIB, ketika

${ }^{23} \mathrm{lbid}$. 
korban yang bernama Zainul Efendi, Agus Langgeng dan Sampurno, sedang bermain play station di rumah saudara Eko yang beralamat di Gowa kelurahan Blimbing kecamatan Paciran kabupaten Lamongan didatangi oleh tiga orang anggota FPI yang bernama Viki alias Gondok, Zen alias Kayak dan seorang lagi yang tidak diketahui namanya, kemudian bertanya kepada korban "siapa yang meludahi temannya (anggota FPI)?”. ${ }^{24}$

Sebelum sempat dijawab, pelaku atas nama Viki membacok Zainul Efendi dengan pedang mengenai kepala, pipi dan punggung. Kemudian saudara Zen memukul Zainul Efendi dengan menggunakan punggung pedang yang dibawanya. Setelah itu menendang leher dan membacok kepala saudara Sampurno. Kemudian Zen menendang dan memukul pipi saudara Agus Langgeng selain itu Zen juga membacok telinga kanan Zainul Arifin dan pelaku yang tidak dikenal memukul Sampurno. Dengan adanya kejadian penganiayaan di rumah saudara Eko, kemudian sekelompok warga kelurahan Blimbing Kecamatan Paciran Kabupaten Lamongan yang salah satunya bernama Raden alamat Gowa Kelurahan Blimbing pada hari minggu tanggal 11 Agustus 2013, sekitar jam 23:30 WIB. Mendatangi rumah Zen di Gowa Kelurahan Blimbing untuk balas dendam. Kemudian ketika sampai di rumah Zen, Zen tidak ada di tempat dan hanya bertemu dengan istri Zen yang bernama Sundari, selain itu kelompok Raden melakukan penganiayaan terhadap Sundari (istri Zen) dengan menggunakan senjata tajam hingga mengalami luka bacok pada punggung dan tangan, selain itu juga melakukan penganiayaan terhadap Riyan hingga mengalami luka di bagian kepala. ${ }^{25}$

Dengan adanya kejadian tersebut, kemudian kelompok FPI kecamatan Paciran yang dipimpin oleh Faruk Mubarok beserta anggotanya sebanyak 42 orang mendatangi rumah Muklis di dusun Dengok desa Kandangsemangkon kecamatan Paciran kabupaten Lamongan. Kemudian melakukan pengrusakan terhadap 6 unit sepedah motor milik warga yang ada disekitar rumah Muklis. Setelah melakukan pengrusakan tersebut, kemudian kelompok FPI juga membakar 2 unit sepeda motor milik warga, selain itu anggota FPI

\footnotetext{
${ }^{24}$ Data dari Kepolisian Negara Republik Indonesia Daerah Jawa Timur Resort Lamongan. ${ }^{25}$ Ibid.
} 
juga melakukan penganiayaan terhadap korban bernama Hamzah dengan menggunakan senjata tajam sehingga mengalami bacok pada telinga dan punggung. Setelah itu FPI membubarkan diri. ${ }^{26}$

Berkaitan dengan kasus yang terjadi petugas Polres Lamongan beserta petugas gabungan dari Polsek Jajaran pada hari Senin tanggal 12 Agustus 2013 sekitar jam 03:30 berhasil mengamankan 42 orang masa FPI Kecamatan Paciran Lamongan dibawah pimpinan Umar Faruq, 36 Unit Handphone milik masa FPI Kecamatan Paciran Lamongan, 9 bilah pedang atau samurai, 14 bilah perang atau golok, 4 bilah celurit, 4 bilah sangkur, 7 bilah pisau, 1 buah selang dan 5 batang kayu. ${ }^{27}$

Di hari yang sama petugas Polres Lamongan juga telah berhasil mengamankan masyarakat Kelurahan Blimbing Kecamatan Paciran Kabupaten Lamongan yang diduga sebagai pelaku penyerangan rumah Zen di Kampung Gowa Kelurahan Blimbing dan Slamet Hadiyono alias Raden di rumahnya Dusun Dengok Desa Kandangsemangkon. ${ }^{28}$

3. Kronologi kasus versi Zainul Efendi selaku korban

Zainul Efendi hanyalah sebagai korban yang tidak tahu apaapa tentang kasus yang ada, akan tetapi sepulang dari tempat play station, dia dan kedua temannya yaitu Agus dan Sampurno, langsung dipukuli oleh anggota FPI yang bernama Kayak alias Zen dan Gondok. Setelah kejadian tersebut, Muklis yang selaku ketua geng tidak terima dengan adanya pemukulan terhadap anak buahnya, oleh karena itu anggota ahli narkoba dan minum-minuman keras membalas dendam mencari Kayak alias Zen ke rumahnya, akan tetapi Zen melarikan diri dan yang ada hanyalah istrinya yang sehingga dibacok tangannya oleh anggota geng. ${ }^{29}$

Setelah kejadian itu anggota FPI semakin naik darah, sehingga mereka membawa anggota-anggotanya yang dipimpin oleh Faruk dengan mencari anggota-anggota ahli narkoba dan minum-minuman keras tersebut. Akan tetapi sebelum adanya penyerangan dari anggota FPI memang anggota ahli narkoba dan minum-minuman keras telah melapor kepada Kapolri Paciran untuk berjaga-jaga. Perencanaan

\footnotetext{
${ }^{26} \mathrm{lbid}$

${ }^{27} \mathrm{lbid}$.

${ }^{28} \mathrm{lbid}$.

${ }^{29}$ Zainul Effendi, Wawancara, Lamongan, 02 Juni 2014.
} 
yang dilakukan oleh Muklis ini dikarenakan Muklis balas dendam terhadap anggota FPI, karena anggota FPI sering menculik anggotaanggota dari Muklis yang sudah diincar dari awal untuk dipukuli, anggota FPI memukulinya tidak pada muka tetapi pada ulu hati yang menjadi kelemahan manusia. ${ }^{30}$

Selain penculikan yang dilakukan, FPI juga memporakporandakan warung-warung kopi di Dusun Dengok sebelum pukul 11:00, padahal warung-warung di sana telah memiliki izin buka sampai pukul 11:00 malam. Anggota FPI kebanyakan menggunakan cadar dalam aksi lapangannya kecuali hanya ketua dan yang memiliki jabatan di bawahnya. Inilah yang mengakibatkan anggota peminum minuman keras semakin membenci organisasi FPI yang mengatas namakan agama sebagai aksi anarkisnya, sehingga sampai menimbulkan kasus yang begitu besar. ${ }^{31}$

Akan tetapi kasus tersebut berakhir dengan damai, hal ini adanya rasa takut Muklis dengan ancaman FPI yang mengenai keluarganya karena latar belakang keanggotannya, FPI kebanyakan dari mantan-mantan mafia yang juga teman Muklis sendiri. Oleh karena itu sedikit banyak anggota FPI juga mengetahui latar belakang sekaligus kelemahan Muklis. ${ }^{32}$

4. Kronologi kasus versi Bapak KH Mardollah selaku tokoh agama di dusun Dengok

Menurut bapak KH. Mardollah:

"iku awale teko masalah seng remeh, anggota ahli narkoba dan minum minuman keras iku ngidu nok ngarepe salah sijine anggota FPI, teros FPI ngroso nek dilecehno, tapi jare seng ngidoni yo gak rumongso nek nglecehno FPI dekne mok ngidu biasa nok ngarepe. Teros seng FPI kondo koncone laine moro diparani teros digepuki mogo ditakoni gak ngaku". ${ }^{33}$

Kasus tersebut berawal dari hal sepele yaitu ludah. Anggota ahli narkoba dan minum-minuman keras menjatuhkan ludahnya tepat di depan salah satu anggota FPI yang sedang menasehati anggota geng. Anggota FPIpun tidak menerimanya, karena

\footnotetext{
${ }^{30} \mathrm{lbid}$.

${ }^{31} \mathrm{lbid}$

${ }^{32}$ Muklis, Wawancara, Lamongan, 11 Juni 2014.

${ }^{33}$ Mardolah, Wawancara, Lamongan, 1 juni 2014.
} 
dianggapnya anggota ahli narkoba dan minum-minuman keras melecehkan mereka, karena sebelum adanya itu memang anggota FPI dan anggota ahli narkoba dan minum-minuman keras di sana sudah tidaklah bersahabat. Kemudian salah satu anggota FPI tersebut bilang sama teman-temannya yang lain, sehingga temantemannya pun membalas dendam atas perbuatan yang dilakukan terhadap temannya, kemudian anggota ahli narkoba dan minumminuman keras tidak terima adanya pukulan-pukulan dan bacokan tersebut, akhirnya anggota ahli narkoba dan minumminuman keras membalas dendam perbuatan FPI dengan mencari anggota FPI tersebut ke rumahnya, karena yang dicari tidak ada maka rumah, kaca jendela, TV dirusak serta pembacokan terhadap istri anggota FPI. Dari situlah akhirnya FPI membalas dendam lagi kepada anggota geng, namun ternyata anggota ahli narkoba dan minum minuman keras sudah melapor ke Kapolsek Paciran terlebih dahulu agar semua yang terjadi seakan-akan FPI yang disalahkan. Dari sinilah Permusuhan yang mengakibatkan keluarnya darah dari tubuh terjadi. ${ }^{34}$

Jadi menurut bapak Mardolah jika menangani orang-orang yang suka berbuat maksiat langsung diserahkan kepada pihak yang berwajib agar tidak terjadi kesalahpahaman. Karena jika orang-orang maksiat diperlakukan dengan hawa nafsu kita sendiri maka akan menentang dan menimbulkan permusuhan.

\section{Tinjauan Hukum Pidana Islam terhadap Kekerasan yang Dilakukan oleh FPI di Dusun Dengok Desa Kandangsemangkon}

Setiap muslim mempunyai kewajiban untuk melakukan dakwah Islam artinya dakwah Islam itu merupaka tanggungjawab setiap muslim, akan tetapi kewajiban ini tidak dapat dilakukan oleh sembarang orang Islam karena terdapat syarat-syarat dan ketentuan-ketentuan yang harus dipenuhi bagi orang yang melakukan dakwah amar ma' ruf nahi munkar, namun persoalannya banyak orang yang tidak mengerti bagaimana metode dakwah Islam mesti dilaksanakan. Banyak orang-orang yang melakukan dakwah itu dengan cara anarkis atau kekerasan seperti halnya yang dilakukan oleh Organisasi Front Pembela Islam.

34 Ibid. 
Front Pembela Islam telah melakukan amar ma' ruf nahi munkar yang perbuatan munkarnya sudah selesai terjadi atau telah berlalu, maka hal tersebut tidak termasuk wilayah nahi munkar tetapi masuk wilayah memberikan sanksi hukuman yang merupakan wewenang penguasa dan bukan wewenang individu perorangan atau kelompok. Jika dalam kasus yang seperti ini ada individu atau sekelompok orang yang melakukan nahi munkar hingga terjadi kekerasan yang menyakiti atau mengakibatkan luka, maka perbuatannya termasuk tindak pidana. Apabila kemunkaran hanya bersifat kemungkinan kejadiannya, seperti ada tempat yang siap-siap akan dijadikan tempat berpesta miras, maka hal ini adalah termasuk ranah memberi peringatan dan nasehat, dan perbuatan yang melebihi hal tersebut seperti kekerasan, penamparan dan pemukulan, maka termasuk perbuatan tindak pidana, bahkan jika tidak ada pengakuan atas rencana kemunkaran, maka tidak boleh ada pemberian nasehat, karena nasehat atas tidak adanya pengakuan atas rencana kemunkaran adalah termasuk kategori perbuatan buruk sangka. Kekerasan yang dilakukan Front Pembela Islam ini berupa penganiayaan-penganiayaan dan ini telah memenuhi unsur-unsur yang ada pada hukum pidana Islam yang digolongkan pada tindak pidana atas selain jiwa.

Adapun pengklasifikasian tindak pidana yang ditimbulkan adanya kasus tersebut adalah:

1. Pelukaan mengenai telinga

Dilihat dari segi objeknya, penganiayaan ini masuk pada tindak pidana penganiayaan atas anggota badan atau atrâf dan semacamnya, yang tidak mengakibatkan perusakan pendengaran akan tetapi menimbulkan cacat. Karena dilakukannya penganiaan ini dengan sengaja, maka hukuman yang diberikan kepada pelaku adalah hukuman pokok yaitu qishâsh, sedangkan hukuman penggantinya adalah diyat atau ta'zîr (hukuman yang diserahkan kepada penguasa)

2. Pemukulan mengenai punggung

Hal ini termasuk pada tindak pidana atas selain jiwa yang bagian kelima yaitu tindak pidana yang tidak masuk pada atrâf, menghilangkan manfaat anggota badan sedangkan jenisnya tetap utuh, al-Syajjâj maupun al-Jirâh. Tindak pidana ini menurut fuqaha tindakan penempelengan, pemukulan dengan cambuk dan tongkat semuanya itu tidak dikenakan hukum qishâsh apabila tidak 
meninggalkan bekas. Akan tetapi jika tidak mengakibatkan luka, maka hukumannya adalah ganti rugi yang ketentuannya kepada kebijakan dan ijtihad hakim. Dalam menentukan besarnya hukumah ini, disyaratkan apabila pelukaan mengenai anggota badan yang diatnya tertentu, seperti tangan, kaki, hukumah tidak boleh mencapai jumlah tertentu. Mengenai hal ini, maka hakim berdasarkan ijtihadnya berhak menguranginya. Di samping itu perlu diperhatikan bahwa perhitungan atau perkiraan tersebut dilakukan setelah korban sembuh dari lukanya dan dilakukan oleh orang yang ahli yang kemudian dijadikan pegangan oleh hakim dalam memutuskan hukumannya. Namun hakim sendiri juga berhak untuk melakukan ijtihad dalam menentukan hukumah tersebut. Para ulama bersepakat bahwa hukumah wajib diberikan apabila yang sembuh itu mengakibatkan cacat. Apabila luka tidak menimbulkan cacat, atau tidak ada bekas luka, para ulama berbeda pendapat; menurut Imam syafi'i dan Imam Ahmad, hukumah tetap harus dilaksanakan meskipun luka sembuh tanpa cacat. Menurut Imam Malik, hukumannya bukan hukûmah, melainkan ta'zîr .

Menurut Imam Abu Yusuf hukumannya adalah hukûmah karena walaupun bagaimana, luka tersebut menimbulkan rasa sakit. Sedangkan menurut Muhammad ibn Hasan, pelaku hanya dikenakan ganti rugi sebagai pengganti biaya pengobatan. Menurut penulis sendiri, hukûmah harus dilaksanakan pada pelaku tersebut, meskipun lukanya sembuh tanpa adanya cacat karena jika pelaku tidak dikenakan hukumah maka pelaku semakin sewenang-wenang dalam berbuat.

3. Pelukaan pada kepala dan pipi

Ada bagian tersendiri yang dalam hukum pidana Islam masuk pada sajjâj yaitu pelukaan pada bagian muka dan kepala. Imam Abu Hanifah membagi sajjâj ini kepada 11 bagian, mulai dari yang paling ringan yaitu al-kharishah dan yang paling berat yaitu al-damighah. Akan tetapi pelukaan yang dilakukan dalam kasus tersebut tergolong pada jenis al-damiyah yaitu pelukaan yang berakibat mengalirnya darah. Pelukaan ini para fuqaha berbeda pendapat tentang ditetapkannya hukuman qishâsh.

Imam Malik berpendapat bahwa dalam jenis sajjâj tersebut, hukuman qishâsh diberlakukan karena hal itu masih mungkin untuk 
dilaksanakan. Akan tetapi menurut Abu Hanifah, yang mengacu pada riwayat al-Hasan, tidak ada qishâsh kecuali pada jenis simhaq (yaitu pelukaan yang memotong daging lebih dalam lagi dari pada almutalahimah, sehingga kulit halus (selaput) antara daging dan tulang kelihatan, selaputnya sendiri yang disebut simhaq) dan mudhihah (yaitu pelukaan yang lebih dalam, sehingga memotong atau merobek selaput tersebut dan tulangnya kelihatan). Sementara menurut Imam Muhammad qishâsh masih dapat diterapkan pada sajjaj yang jenisnya mudhihah, simhaq, badhi'ah dan damiyah, karena kesepadanan masih mungkin dilaksanakan dengan mengukur lukanya, baik lebar maupun dalamnya. Akan tetapi menurut madzhab Syafi'i dan Hambali, tidak ada hukuman qishâsh pada sajjaj sebelum mudhihah, karena luka-luka tersebut tidak sampai pada tulang, sehingga tidak ada batas yang aman dari kelebihan. Menurut penulis, tidak ada hukum qishâsh pada jenis al-damiyah, karena tidak ada batas yang aman dari kelebihan padahal hukuman qishâsh tidak boleh diberikan lebih dari pelukaan yang pelaku perbuat. Jika hukuman qishâsh tidak bisa dilaksanakan karena ada suatu halangan, maka dapat dihukumi dengan diyat (ganti rugi). Untuk sajjaj di bawah mudhihah, para ulama telah bersepakat bahwa tidak ada ganti rugi yang tertentu artinya ganti rugi yang besarnya diserahkan kepada keputusan hakim. Akan tetapi ada satu riwayat dari Imam Ahmad, bahwa untuk damiyah dikenakan satu ekor unta. ${ }^{35}$

Dilihat dari kasus tersebut memang seakan-akan hanya kasus kriminal biasa, akan tetapi jika diteliti lebih dalam kasus tersebut disebabkan adanya praktek amar ma'ruf nahi munkar yang tidak memenuhi syarat dan ketentuan-ketentuan yang ada dalam Islam. Dari sinilah kenapa Front Pembela Islam sering berbenturan dengan ahli maksiat. Front Pembela Islam melakukan perbuatan tersebut berdasarkan hadis:

Barangsipa melihat kemunkaran, maka ubahlah dengan tangannya (bila mampu), bila tidak mampu, maka ubahlah (berantaslah) dengan lidahnya (yaitu memberinya peringatan yang baik, boleh keras dan boleh juga lemah, asal melihat mana yang bermanfaat untuk agama) Apabila masih tidak

\footnotetext{
${ }^{35}$ Abd Al-Qadir Audah, at-Tasyrî̃ al- Jinai al-Islâmiy, Juz Il (Beirut: Dar al-Kutub, 1963), 280.
} 
mampu, maka cukup (benci) di hati. Dan itulah iman yang paling lemah. ${ }^{36}$

Menurut al-Qur'an, dakwah dalam rangka amar ma'ruf nahi munkar harus dilakukan sesuai dengan prinsip-prinsip dan tiga metode yaitu dengan mengemukakan hikmah (perkataan yang tegas dan benar yang dapat membedakan antara yang haq dan yang batil), pengajaran yang baik dan diskusi atau berdebat dengan cara yang baik untuk menaruh perhatian, karena cara yang salah akan berakibat enggan menerima kebenaran. Sesuai dengan QS al-Nahl ayat 125:

Serulah (manusia) kepada jalan Tuhanmu dengan hikmah dan pelajaran yang baik dan bantahlah mereka dengan cara yang baik. Sesungguhnya Tuhanmu Dialah yang lebih mengetahui tentang siapa yang tersesat dari jalanNya dan Dialah yang lebih mengetahui orang-orang yang mendapat petunjuk. ${ }^{37}$

Statemen al-Qur'an ini tidak mengisyaratkan penggunaan tindakan anarkis dalam memberantas kemunkaran. Penggunaan tindakan anarkis dalam memberantas kemunkaran bukanlah suatu langkah yang Islami atau amar ma'ruf nahi munkar. Justru tindakan itu merupakan amar munkar bukan nahi munkar. Karena itu pemberantasan kemunkaran tetap harus dilakukan dengan cara-cara yang sesuai dengan etika dan hukum Islam atau tidak melanggar etika dan hukum Islam. Berdasarkan dalil al-Qur'an inilah cara-cara yang seharusnya dipakai dalam melaksanakan amar ma' ruf nahi munkar karena bagaimanapun juga al-Qur'an lebih tinggi dibandingkan dengan hadis. Sebagaimana dijelaskan dalam teori ushul fiqh bahwa jika ada kontradiksi antara dua hadis atau antara hadis dengan nas alQur'an, maka mengutamakan dan mengedepankan dalil yang lebih kuat terhadap dalil yang lebih lemah (tarjih). Tarjih bisa melalui aspek matan. Misalnya mendahulukan yang paling kuat dilalahnya, seperti mendahulukan muhkam atas mufassar, atau ibârah atas isyârah. Tarjih juga bisa melalui aspek sanad, misalnya mutawâtir didahulukan atas âhâd, masyhûr atas satu orang, yang didukung banyak dalil atas yang sedikit dalil, atau yang menjadi pertimbangan

\footnotetext{
${ }^{36}$ Al-Imam Abu Zakariya Yahya, Riyâdh ash-Shâlihîn, 268.
}

${ }^{37}$ Hamka, Tafsir Al-Azhar, 319. 
tarjih adalah kelebihan rawi dari segi kefaqihan, adil, dhabit dan keilmuan atau lainnya. ${ }^{38}$

Merubah dengan tangan dalam hadis tersebut adalah bukan dengan tangan kita, tidak lain adalah dengan kekuasaan. Oleh karena itu, haruslah ada segolongan orang atau satu kekuasaan yang menyeru kepada kebajikan dan mencegah dari yang munkar. Ketetapan bahwa harus ada suatu kekuasaan adalah kandungan petunjuk nash alQur'an. Negara adalah lembaga sosial yang diadakan manusia untuk memenuhi kebutuhan-kebutuhannya yang vital. Sebagai lembaga sosial negara tidak diperuntukkan memenuhi kebutuhan khusus dari segolongan orang tertentu, tetapi untuk memenuhi keperluankeperluan dari seluruh rakyat negara itu. ${ }^{39}$

Menurut ajaran Islam tujuan negara adalah terlaksananya ajaran ajaran al-Qur'an dan Sunnah Rasul dalam kehidupan masyarakat, menuju kepada tercapainya kesejahteraan hidup di dunia, material dan spiritual, perseorangan dan kelompok serta mengantarkan kepada tercapainya kebahagiaan hidup diakhirat kelak. Kewajiban pertama atas seorang penguasa dan pemerintahannya, dalam negara Islam ialah menegakkan sistem kehidupan Islami dengan sempurna tanpa mengurangi atau menganti. Dan wajib atasnya memerintahkan segala yang ma'ruf, menebarkan kabaikan dan mencegah kemunkaran serta bertindak membasmi kejahatan dan kerusakan sesuai dengan nilai-nilai akhlak Islam. ${ }^{40}$

Indonesia adalah negara hukum oleh karena itu yang berhak menegakkan Amar ma'ruf nahi munkar adalah yang memiliki kekuasaan (intansi yang berwenang). Akan tetapi jika yang melakukan amar ma'ruf nahi munkar adalah selain yang berkuasa maka akan menimbulkan kesalahpahaman sehingga menimbulkan balas dendam dan menjadikan kasus yang begitu besar seperti halnya kasus yang ada. ${ }^{41}$

Apabila dakwah itu dapat dilakukan oleh orang yang tidak memiliki kekuasaan maka perintah dan larangan itu tidak akan dapat dilakukan kecuali oleh orang yang memiliki kekuasaan untuk dapat

\footnotetext{
${ }^{38}$ Wahbah Zuhaili, Ushul al-Figh al-Islâmiy (Beirut: Dar al-Fikr, 1985), 481.

${ }^{39} \mathrm{Ni}$ 'matul Huda, IImu Negara (Jakarta: Rajawali Pers, 2011), 53

${ }^{40} \mathrm{Ibid}, 58$.

${ }^{41}$ Sutiono, Wawancara, di Kapolda Jawa Timur, 16 juni 2014.
} 
memerintah manusia agar dapat dipatuhinya sebagaimana firman Allah surat an-Nisa' ayat 64:

Dan Kami tidak mengutus seseorang Rasul melainkan untuk ditaati dengan seizin Allah. ${ }^{42}$

Tujuan menegakkan kekuasaan (negara) adalah untuk memerintah dan melarang, mewujudkan yang ma'ruf dan meniadakan kemunkaran dari kehidupan manusia dan memelihara kebiasaan yang bagus agar jangan disia siakan oleh orang-orang yang hendak mengikuti hawa nafsu, keinginan dan kepentingan. Juga untuk melindungi kebiasaan yang shaleh ini agar setiap orang tidak berkata menurut pikiran dan pandangannya sendirii karena menganggap bahwa pikirannya itulah yang baik, ma' ruf dan benar. ${ }^{43}$

Begitulah pandangan Islam terhadap masalah ini bahwa di sana harus ada kekuasaan untuk memerintah dan melarang, melaksanakan seruan kepada kebaikan dan mencegah kemunkaran. Rasulullah saw bersabda:

"Melalui negara, Allah membasmi semua yang tidak dapat dibasmi melalui al-Qur'an".

Artinya kesejahteraan yang tidak dapat dimusnahkan melalui ajaran-ajaran al-Qur'an membutuhkan kekuasaan memaksa dari negara untuk membasminya. Hal ini berarti tujuan utama suatu negara Islam adalah untuk menegakkan dan melaksanakan dengan segenap sumber daya kekuasaannya yang terorganisasikan sejalan dengan program reformasi yang telah ditunjukkan Islam demi tegaknya kehidupan yang lebih layak untuk perbaikan umat manusia. $^{44}$

\section{Simpulan}

Kekerasan yang dilakukan oleh anggota Front Pembela Islam, bermula pada anggota ahli narkoba dan minum-minuman keras yang menjatuhkan ludahnya tepat di depan salah satu anggota Front Pembela Islam, yang sedang menasehati anggota ahli narkoba dan minumminuman keras yang diduga sedang pesta miras. Anggota Front Pembela Islampun tidak terima, karena dianggapnya anggota ahli narkoba dan

\footnotetext{
${ }^{42}$ Sayyid Quthb, Tafsîr Fî zhilâl al-Qur'ân (Jakarta: Gema Insasi Pers, 2001), 122.

${ }^{43} \mathrm{lbid}$.

${ }^{44}$ Ni'matul Huda, Ilmu Negara ..., 59
} 
minum minuman keras melecehkan mereka. Kemudian salah satu anggota Front Pembela Islam tersebut mengadu kepada temantemannya, sehingga teman-temannya menganiaya dan melukai anggota ahli narkoba dan minum-minuman keras. Dari sinilah timbul pembalas dendaman antara anggota FPI dan anggota geng yang ada di Dusun Dengok Desa Kandangsemangkon

Penganiayaan-penganiayaan yang dilakukan oleh anggota Front Pembela Islam yang ada di Dusun Dengok Desa Kandangsemangkon ini telah memenuhi unsur-unsur yang ada pada hukum pidana Islam yang digolongkan pada tindak pidana atas selain jiwa. Adapun yang dilakukan antara lain adalah pemotongan telinga, pemukulan mengenai punggung, pelukaan pada kepala dan pipi. Dalam hukum pidana Islam, kekerasan dan pelukaan secara massa yang mengakibatkan luka orang lain ini tidak diatur secara langsung, namun dapat dikualifikasikan sebagai jarîmah penganiayaan yang dilakukan secara bersama-sama, maka qishâsh dijatuhkan atas pelaku aktif yaitu pelaku langsung, namun jika ada pemaafan dari korban, maka pelaku bisa membayar diyat atau bebas, sedangkan pelaku tidak langsung dalam hal ini dijatuhi hukuman ta'zîr yang diserahkan kepada hakim.

\section{Daftar Rujukan}

(ad)-Damsyaqi, Al-Imam Abu Zakariya Yahya bin Syarif An-Nawawi. diterjemahkan oleh Mahrus Ali. Riyâdh ash-Shâlihîn. Surabaya: al-Hidayah, 1997.

Anshor. Wawancara. Lamongan, 03 Juni 2014.

Audah, Abd Al-Qadir. at-Tasyrî̀ al- Jinai al-Islâmiy. Beirut: Dar alKutub, 1963.

A-Zastrouw. Gerakan Islam Simbolik Politik Kepentingan FPI. Yogjakarta: PT LKiS Pelangi AksaraYogjakarta, 2006.

Data dari Kepolisian Negara Republik Indonesia Daerah Jawa Timur Resort Lamongan.

Departemen Agama. Al-Qur'an dan Terjemahnya. Jakarta: Surya Cipta Aksara Surabaya, 1993.

Efendi, Syahrul dan Yudi Pramuko. Rahasia Sukses Dakwah Habib-FPI Gempur Playboy. Jakarta: Devisi Buku Dakwah dan Bisnis, 2006.

Effendi, Zainul. Wawancara. Lamongan, 02 Juni 2014. 
Hamka. Tafsir Al-Azhar. Juz XVII, Surabaya: Bina Ilmu, 1981.

http://www.tempo.co/read/news/2013/08/12/06350384 i/ Ini-

Kronologi-Bentrok-FPI-danWarga-di-Lamongan.

Huda, Ni’matul. Ilmu Negara. Jakarta: Rajawali Pers, 2011.

Mardolah. Wawancara. Lamongan, 1 juni 2014.

Muklis. Wawancara. Lamongan, 11 Juni 2014.

Qardhawi, Yusuf. Fiqih Jihad sebuah Karya Monumental Terlengkap tentang Jihad menurut al-Qur'an dan Sunnah, Bandung: PT Mizan Pustaka, 2010.

Quthb, Sayyid. Tafsîr Fî Dzilâl al-Qurân. Jakarta: Gema Insani Pers, 2001.

Sabili, No 13 Tb. VII 13 Desember 2000.

Salim. Wawancara. Lamongan, 5 juni 2014.

Setiawan. "Orientasi Tindakan dalam Gerakan Nahi Munkar Laskar Front Pembela Islam (Jogjakarta)", -Skripsi-, Jogjakarta: Fakultas Ushuluddin Universitas Islam Negeri Sunan Kalijaga, 2009.

Sutiono. Wawancara. Kantor Kapolda Jawa Timur, 16 juni 2014.

Syihab, Al-Habib Muhammad Rizieq bin Husein. Dialog Amar Ma'ruf Nahiy Munkar, Menjawab Berbagai Tuduhan terhadap Gerakan Amar Ma'ruf Nahiy Munkar di Indonesia. Jakarta: PIS, tt.

Al-Habib Muhammad Rizieq Husein. Dialog FPI: Amar Ma'ruf Nahi Munkar. Jakarta: CV Ibnu Sidah, 2013.

Zuhaili, Wahbah. Ushûl al-Fiqh al-Islâmiy. Beirut: Dar al-Fikr, 1985. 